\title{
Zimbabwe Economic Sanctions and Post-Colonial Hangover: A Critique of Zimbabwe Democracy Economic Recovery Act (ZDERA) - 2001 a2018
}

\author{
Munoda Mararike ${ }^{1}$ \\ ${ }^{1}$ London Middlesex University, Department of Law and Politics, Room W36, The Borough, NW4 4BT, London, United \\ Kingdom \\ Correspondence: Munoda Mararike, London Middlesex University, Department of Law and Politics, Room W36, The \\ Borough, NW4 4BT, London, United Kingdom.
}

Received: August 8, 2018

Accepted: November 19, 2018

Available online: December 21, 2018

doi:10.11114/ijsss.v7i1.3895

URL: https://doi.org/10.11114/ijsss.v7i1.3895

\begin{abstract}
"Considering how thorough-going was the capture of the minds of the Blacks, it is really not surprising that so many Negro scholars still faithfully follow in the footsteps of their white masters. I was convinced that what troubled me and what I wanted to know, was what troubled the black masses and what they wanted to know. We wanted to know the whole truth, good and bad. For it would be a continuing degradation of the African people if we simply destroyed the present system of racial lies embedded in world literature only to replace it with glorified fiction based more on wishful thinking than on the labors of historical research."
\end{abstract}

- Chancellor Williams, The Destruction of Black Civilisation: Great Issues of Race from 4500 B.C to 2000 A.D

\begin{abstract}
Scholarship on imperialism in Zimbabwe has not been documented in terms of establishing its roots. What has evaded contemporary researchers and academics on post-land reform programme economic sanctions of 2001 is that their roots lie in colonial domination and imperialism. The Scramble for Africa of 1884 is an adjunct of the Berlin Colonial Conference of 1884-1885 which marked long dark days of imperialism in Africa. It was about colonial domination, exploitation of mineral and extraction of natural resources. Western Europe became principal beneficiaries of newly 'discovered' wealth - pillaging and looting to their countries through exploitation, false pretenses, deception and outright theft. The insidious process was complemented by subjective constructs of political, social, religious and cultural domination of indigenous populations or 'natives' as imperialism defined unbalanced framework of economic relationships. Pronunciations like subjugation, suppression, cultural genocide, expropriation and repression have been touted by historians to highlight the depth and intensity of coloniality. The economic sanctions are part of a strategic neo-colonial era in which former colonial powers continue clutching to vein glories of the past. Yet that past is the present. Zimbabwe is being punished for reclaiming land through land reform programmes of 2001 which helped to empower Zimbabweans. In this research we look at the Janus face of Western decoloniality efforts- with specific reference to how Zimbabwe has fought ferocious battles for reclamation and restitution of its land. We also examine instruments of repression including statutes like the 1965 Unilateral Declaration of Independence (UDI) and the Zimbabwe Democracy and Economic Recovery Act of 2001 as amended in 2018 (ZDERA). In our analytical narratives, we illustrate how the such instruments are designed to maintain imperialist status quo through specified punitive measures under ZDERA.
\end{abstract}

Keywords: colonialism, reclamation, domination, repression subjugation, consciousness

\section{Introduction}

Chimurenga is a name given to colonial resistance borne out of the Pioneer Column of September 12, 1890 when Zimbabwe was occupied by colonialists and named Rhodesia after an imperialist called Cecil John Rhodes. Zimbabweans then waged a war of colonial resistance against settlers who swamped the region destined to exploit new found wealth. Throughout the colonial rule, 'native' Zimbabweans continued to be exploited through passage of various 
legislations that reinforced apartheid type of governance based on racial discrimination, exploitation of cheap labour and domination. From thereon, we witness the period in which 'native' Zimbabweans fought hard to regain back their land. The second watershed entails a dark phase of history in which the settler Rhodesian regime Declared Independence through the Unilateral declaration of Independence (UDI) in November 1965. This resulted in the imposition of punitive sanctions as desired by the British government for Rhodesian defiance of the British Crown. The second phase is a build-up of African nationalism in which they took arms to fight for their land resulting in negotiated Lancaster House constitution that gave birth to Zimbabwe in 1980.

The third phase of "Chimurenga War of Liberation" known as "Hondo Yeminda" in local language started in 2001 when the Zimbabwe African National Union - Patriotic Front (ZANU-PF) government, under President Robert Mugabe promulgated legislation for land reform - involving land re-distribution. This is the point at which Britain lobbied for sanctions to be imposed on Zimbabwe. There are mixed views about this phase: For others, it postulates Mugabeism as anti-colonial and anti-imperialist stance - some kind of defiance. Mugabe became the face of resistance and struggles against imperialism. For others, the phase defines Mugabe as a brutal and iron-fisted dictator who was ruthless with his opponents including Western governments and the EU, for implementing economic sanctions and individual restrictive measures.

The re-assertion of demands for equality, African-ness and African unity reflect the loathing of settler colonial domination and a quest for self-determination. By resolving the land question, Zimbabwe engaged in a long process of anti-colonial resistances and political struggles aimed at reversing exploitation of economic resources by the West. It is also a creation of new spaces in the discourse and exchange of ideas on strengthening self-rule and true independence designed to empower indigenous populations that suffered from residual and cumulative effects of colonialism. This is a transcript of a struggle from where other countries will read some of the formulas for land reform programme through re-acquisition and re-possession without regret. If not, then it will be through spiritual guidance and political foresight ushered from Zimbabwe's experience. South Africa is engulfed in a similar fake concept of independence that has ensured protectionist policies towards white businesses at the expense of Black empowerment. However, for Zimbabweans to have achieved total liberation, it was necessary for them to go through the process of decolonizing the mind and soul by taking back land that belonged to them in the first place.

Post-independence land reform revolution the "Third Chimurenga" took off in 2001 against the background of the new millennium - another replication of the scramble for Africa in the form of globalisation. What had preceded the third Chimurenga was the enactment of a deeply flawed constitution by the British legitimising and regulating political systems at independence in 1980. The root of this war was, therefore, anchored on the Lancaster House Agreement (LHA) of 1979, which gave a caesarean birth of the new nation in 1980. [1]. The basic objectives of the Land Reform Programme [LRP] were rooted in reversing the Lancaster House Agreement that protected white commercial farmers from losing land under Mugabe's government. The Protectionist policy lasted for 10 years whereupon the government was not allowed to change land tenure and ownership by constitutional means.

I highlight the statement of the problem that the Lancaster House Agreement did not address constitutional demands for Zimbabwe land reforms. The LHA was in fact a legislative instrument that was used to reinforce 'British imperialism' by seeking to preserve the colonial status quo. It is around the false sense of 'independence' that nationalist leaders like Sithole, Chikerema, Joshua Nkomo, Josiah Chinamano, Herbert Chitepo, Morris Nyagumbo Edgar Tekere, Emmerson Mnangagwa, and Robert Mugabe mobilised forces to fight coloniality and neo-colonialism that was entrenched in the terms and conditions of their independence. Viewed from another angle, the 1979 Lancaster House Agreement [2] was an attempt to dilute the benefits and reverse gains of the Zimbabwean Liberation struggle [3]. From another angle, it was designed to protect and protract white hegemony in Zimbabwe at the expense of Black Nationalism and Renaissance. The Agreement turned out largely to be an affront to the armed struggle which was waged on the premise of total liberation of the majority from colonial oppression and a promise to reclaim land which was stolen during the colonial era. The objective of this study is to unpick not only where the third Chimurenga started from, but analyse how the West, especially Britain responded to the Zimbabwean crisis.

This qualitative research formulates research questions designed to gather information and data from secondary sources of data. The National Archives of Zimbabwe contains vast amounts of information on British colonialism in Zimbabwe. I gather information from historical monograms and diaries that confirm that the existence of neo-colonialism and imperialism in Rhodesia was part of a highly sophisticated and planned policy of Britain to maintain her influence even after granting Zimbabwe independence. Research tools include consultation and interface of data using thematic analysis in which the study flows from themes that are intertwined in discourse analysis of nationalism as a response. The paper has sections dedicated the origins of sanctions in both colonial Rhodesia and Zimbabwe, Brexit as a strategy to revive British domination and splendid isolation, functionalist perspectives on economic sanctions, locating Mugabeism as one form of resistance and mobilization 
The study is also assertive in arguing that imperialism as a nihilistic quest by white settler minority for control over vast tracts of land and the mineral resources found in the country. Such strategies were designed to turn Zimbabwe into a backyard of white monopoly capital undergirded by imperialism. As such, in pursuit of social and academic justice, Zimbabwe's decoloniality cannot be discussed adequately outside the context of the social forces at play at three historical epochs, the history, coloniality, and decolonization as part of anti-imperialism. These depredations and banalities of colonialism in Zimbabwe are also reflected in First and Second Chimurenga land struggles dating back to the illegal occupation of Rhodesia by the British Pioneer Column in 1896.

\section{A Theoretical Framework of Sanctions}

According to McGillivray \& Stam (2004: 156) economic sanctions are '...an example of coercive [and cohesive] diplomacy designed to induce a target country to change some policy it would not otherwise...' This means economic sanctions achieve their objectives through deliberate and systematic acts of destructive engagement as they employ sabotage in the interest of sender countries. Are sanctions negative (punishment for deviance and dysfunctionality) or positive (as a measure of instituting reward for compliance)? Clyde-Hufbauer, et al (1985) defines 'sender countries' as [the] principal authors [or architectures] of the sanctions episode while 'target country' denotes the immediate object of the episode. Economic damage of target country is achieved through the systematic reduction of customary trade, sudden withdrawal of financial relations and systems thereby causing maximum damage to the target country and its citizens.

The question of success or failure of sanctions as an instrument of foreign policy enforcement depends on perceptions: First, does the impact of damages caused by sanctions and the resultant suffering of vulnerable population constitute achievement? Whose achievement? In a comprehensive analysis on 1965 Rhodesian sanctions, Galtung (1967:380) observes that:

... It is not obvious that the same action or sanction can serve both purposes; in fact, modern penology does not seem to warrant much belief in punishment as a general method for making people comply. Punishment may have other effects, as when criminals are kept of the streets and isolated in prisons where their deviant actions are hidden from the general view and thus are less consequential to the outside world, but this is not the same as making them comply...

Second, when sanctions are considered a success, is that success measured in terms of extent or degree of suffering of those citizens affected by conflict borne out of international disconnect? How is the impact and successful repeal of sanctions measured at target country levels? Are consequential damages of sanctions an index of success? Whose success? Besides arguments contextualised or situated in platitudes and moral rectitude, who bears vicarious liability or responsibility for damages inflicted to innocent civilians - is it leaders in target countries? Is there moral turpitude and depravity in arguments pushed through by western governments? Who listens? Who cares? What is a sender country expecting from a target country when it triggers a process that is set to destroy acquitted citizens - in the hope of annihilating the system blamed to have brought punitive action in that instance? Whose interests do they serve, and which purpose is dominant? Who rewards the sinners? Who are those sinners? Galtung op cit (228) is at pains to expatiate:

...without belittling the significance of any one of these arguments, it makes good sense to ask a politician engaged in sanction policies, "If you cannot have both, which outcome would you prefer, punishment without compliance or compliance without punishment?" If he insists that punishment is a sufficient condition for compliance, then he is simply naive; if he insists that punishment is a necessary condition for compliance, then he is probably in addition highly punishment-oriented in the sense that punishment has become an automatic and probably also cherished goal. This punishment-oriented attitude is probably ... widespread, particularly as applied to the international system, and serves to maintain negative sanctions. If compliance is not obtained, there is at least the gratification that derives from knowing (or believing) that the sinner gets his due, that the criminal has been punished. In this sense negative sanctions are safer than positive sanctions. And when hatred is strong, positive sanctions would probably be out of the question anyway...

I focus on negative aspects of sanctions from a victim's point of view without regard to international western actors. For example, when the system is indestructible like that of Cuba's revolutionary and ideological mind-set of its citizens, what else can sender countries resort to? Other simple but complex questions in sanctions-imposition narratives matrices pertains to what are termed justifiable offences and human rights violations. For example, where - under a raft of economic embargos - financial aid is suspended resulting in genocide in a target country, are there substantive grounds to prosecute sender countries? How is international law interpreted and why is that such laws tend to be in favour of sending countries?

Proponents of economic sanctions argue that they are effective and unlike military action less debilitating - and therefore safer and cheaper in terms of human cost. Countries like Zimbabwe that have experienced two decades of 
economic sanctions from the time of their imposition in 2001 argue that sanctions are a form of ideological warfare designed to inflict lasting impact in form of regime change. This 'war' is conducted without necessarily deploying or inflicting military action but has landmarks like those sustained in military war situations. Economic and Political scientists like Portela (2010), Sandler \& Hartley (2007) Mararike (2018) argue that success of sanctions is based on motives to employ foreign policies as blunt instruments by dominant sender countries. 'Blunt' as a comparative form of speech is a direct reference to uncompromising, unceremonious and brusque processes of negotiation synonymous with pain and agony. To inflict pain on an animal or a people, whether deliberately or instinctively is to exhibit a high degree of cruelty and bigoty.

However, there has been difficulties in quantifying the 'success' of sanctions especially in situations when a target country does not comply or accede to demands from sender countries. In the case of Zimbabwean sanctions, land reform programme on which sanctions were imposed upon as an indiscriminate punitive measure onto the entire population, land re-distribution was not reversed at the end of the Mugabe era in November 2017. If at all the incoming Mnangagwa government upheld and hailed the Mugabe era land reform as a successful story. By insisting on redistribution of land to Zimbabweans - to both peasants and petit bourgeoisie alike - was a plausible and revolutionary decision on the part of the ruling ZANU PF party. However, the incoming Mnangagwa government was inadvertently sending strident signals to the West. Wary of the fact that the new dispensation was going to uphold ideological values on which the Zimbabwean struggle's $3{ }^{\text {rd }}$ Chimurenga was waged, the West, especially 'Colonial Master' Britain adopted a wait and see attitude. Their inevitable diplomatic face saver was by putting demands and conditions for the lifting of Zimbabwe Democracy and Economic Recovery Act of 2001.

Despite 'smart sanctions' targeted to the ruling elite, there is evidence that majority of Zimbabweans supported land redistribution under Chimurenga 3. Symmetrical and seminal debates confirm that ordinary Zimbabweans explicitly supported their political leaders - even if majority of that populace suffered the most from draconian Western-imposed sanctions. It has been stated that Zimbabweans sanctions are multilateral in that they are being handled by several countries - USA, UK including the European Union. In other words, they are being driven by world economic blocks, because almost all western nations are participating including Australia and New Zealand. Targeted sanctions are aimed at individuals in receiving countries, but this affects the whole country in including individuals and groups like industrialists, Chamber of Commerce executives and those groups that are not particularly responsible. The foregoing creates victims within the innocent populace who serve to reinforce contradictions within the capitalist social structures. This situation is more prominent because those same targeted individuals in Zimbabwe are the ones heading strategic business consortiums, quisi-government organisations and parastatal organisations.

On the same wavelength, opposition politics never challenged or doubted the legitimacy of land reforms as they called for a forensic audit and transparency in the land distribution. In principle, there is consensus across the Zimbabwean population that equitable land distribution is a legitimate justification for dismantling injustices of coloniality and imperialism. What may appear to be a point of debate particularly in opposition politics is the way land was distributed after colonial master Britain reneged on Lancaster House constitutional provisions of 1979.

\section{Wider Implications of Imperialism and Brexit}

What is the Rodinisation doctrine and why is it important and applicable to Zimbabwe? Walter Rodney (1972) is a pan Africanist writer whose classic book How Europe Underdeveloped Africa focuses on European development models at the expense of poor African nations. Rodinism is a doctrine that is based on colonial struggles that dominated the 1960s especially in Africa. In simple terms, colonialism brought unequal relations of power exploitation. Rodinisation is, therefore, a process of exploiting the Africans through subjugation by European nationals who perceived themselves [to be] infinitely superior than their subjects. The process also entails deprivation and destruction of cultural artefacts, norms and values on whose existence is based. The question of language forms part of those cultural norms and belief systems. What this meant is that those that had the power to conquer and vanquish 'natives' by driving them off their land and mineral ore resources became the colonial rulers. By examining the use of power in dominating over poor and mainly African countries in the post-colonial discourse, Rodney uses political relations of exploitation, subjugation, capitalism to advance narratives of underdevelopment of victim states by powerful western nations. Power in this sense does not only mean direct control, but direct rule through institutionalisation of colonial structures of governance - the executive, judiciary and legislature. Those three states apparatus formed colonial governments that ruled and directly controlled all operations of colonial rule. The net effect of colonialism, according to Walter Rodney, meant that 'natives' were consigned to poverty as they existed as part of structured labour pool in the matrices of white governance. When the true owners of countries are colonised, it means loss of their identity and collective sense of purpose. It means divisions of 'natives' into warring tribes who were incapable of uniting against a common enemy.

Walter Rodney argues that exploitation of African countries creates economic trajectories that are entrenched in poverty 
and deprivation. What that statement means is that the exercise and implementation of colonial domination is driven by greed and profit. Colonialism forms the base and superstructures are systems devised by Caucasians to retain control to their benefit. The systems that forms the superstructure in exploitation of men by men include indoctrination via religious dogmas, 'civilisation', education and so forth. It is known that Eurocentric indoctrinations are aimed at completely wiping away relics of cultural symbols and religious artefacts. Rodinisation did not take place in a vacuum but situations that empowered the Europeans through extortion, rapacity, false pretences and outright theft. The resources exploited from colonies are the ones that build the economies of western countries: European gains and African losses are the core of Rodinisation.

\subsection{Rodinisation and Brexit: Reconstruction of Underdevelopment}

Here is why the doctrine is important in interpreting Zimbabwean economic sanctions: In 2016, Britain indicated its intention to come out of the European Union via a referendum. The implication is that that country comes out of the umbrella body, through a hard Brexit deal. In that deal, Britain is set to lose trading economic allies and trading partners. It is set to lose trading deals with the European Union countries. Britain has confirmed splendid isolation policy by negotiating individual trade deals with countries that are willing to trade with her. Britain believes that it will re-negotiate trade protocols and bi or multi-lateral agreements with its traditional trading partners like the USA, Canada Australia and New Zealand. These traditional trading partners are outnumbered by the EU block countries. The reality is that Britain is set to be disadvantaged by its Brexit.

Britain has, of late, searched for trading partners from its former colonies who make up the commonwealth of nations. Zimbabwe is a former colony of Britain. In the post Mugabe era, Britain has made it known that it will cut deals with the second republic of Zimbabwe under President Emmerson Mnangagwa. The fall-out on Brexit has re-directed Britain to consider its trading position with African countries. The competition for African resources with China has helped escalated the process of engagement in Africa - with Theresa May visiting strategic African countries in 2018. Zimbabwe is a Britain's target state because of colonial and cultural links. Britain has a number of transnational countries already set up in Zimbabwe since the colonial days. Britain already enjoys trade with Zimbabwe especially in mineral ore resources, agriculture and natural resources. It is easy for Britain to exploit Zimbabwean resources on the basis of the following:

(a) The new dispensation of the second republic of President Munangagwa is desperate to re-engage with the international community. It makes a lot of sense for this landlocked country to engage through the British government - whose government is leading in maintaining sanctions punitive measures including trade and financial embargos.

(b) The British government has direct influence in Zimbabwean politics particularly in funding and promoting opposition politics in Zimbabwe. Robert Mugabe used to accuse Britain of creating and funding the opposition through financial aid and non-governmental organisations. Britain is aware of the agenda to destroy liberation politics in Zimbabwe. ZANU PF is considered be militant and resilient about nationalist politics - and this has always made Britain uncomfortable about doing business with the Zimbabwean government. The future of British business interests in Zimbabwe lies in the opposition politics because of the foregoing structural fault lines. It is through opposition politics and civil rights groups that Britain will assert dominance and power in Zimbabwe, assuming that it finds a way of doing so.

\section{Discussion: Tracing the Roots of Sanctions}

For us to understand the origins of sanctions in Zimbabwe, we must trace the imperialist agenda. Zimbabwe decolonisation is part of the wider and gigantic imperialist configurations that swept through Europe in the $18^{\text {th }}$ and $19^{\text {th }}$ centuries. The German Chancellor Otto von Bismarck presided over The Kongokonferenz of 1884 to 1885, better known as the Berlin Colonial Conference. The words 'scramble' or 'partition' are very significant. From the Cambridge Dictionary - to scramble is to move or climb quickly but with difficulty, often using your hands to help you; to compete with other people for something there is very little of. Deductive meaning implies desperation and competition for scarce resources. 'Partition' is [often] used to deploy imperial maladies in sharing spoils... which boarder on the derogatory pathologies of robbing a group of nations of their independence. This creates enduring social formations of inequality.

Based on foregoing, scholars seek to underpin colonialism as a process or a condition, the coloniality of being as an identity tag and decolonisation processes as a question of subjectivity. At one other level, coloniality is characterised by patterns of power based on inequality. Scholars like Van Onselene (1976) state 'power' is translated to inter-subjective relations of labour and productivity which he routinely referred to as "Chibharo' [4] or forced labour. Between 1891 and 1895 'Natives Reserves' for Africans later known as 'Tribal trust Lands were created marking the beginning of racial segregation and forced removals of families off their traditional and cultural land. 
In 1893, the first rebellion known as Matebele Uprising took place in protest of white occupancy and racially motivated removals of indigenous groups off their land. This was followed by the First Chimurenga of 1896-97 where natives were defeated by the military mighty of the settlers. What followed this was a raft of repressive legislative instruments designed to consolidate white colonial rule in Rhodesia.

Colonial Rhodesia was a depiction of Master/Servant dialect which contributes to the ontology of coloniality racism. Fanon (2008) draws on extremal expressions of coloniality in relation to racial subjectivity. These characteristics are adjuncts that British imperialism exhibited in their rabid colonial agenda in Zimbabwe.

\section{Literature Review - Key Themes}

The subject of economic sanctions is wide. Academicians and scholars approach the subject from different contextual and theoretical perspectives. According to Weiss (1999) sanctions have invariably been used as a foreign policy tool designed to subjugate former colonies into compliance and submission to imperial demands. In his scholarship expose on sanctions Helms (1999) points out of Washington's 'sanctions madness' which has become an 'epidemic' that defeats the original purposes they serve. There has been growing misgivings about their consistency and transparency as detected by Conlon (1995), Von Braunmuhl, C \& Kulessa, M (1995). Other intellectuals like Jing et al (2003), van Berggeijk (1989) raise serious questions and concerns on the benefits of sanctions in view of aggravated and sustained civilian suffering they cause. Muler \& Muler (1999) note of tribulations exerted on innocent populations as powerful states disproportionately settles scores with weaker nation states. According to the Institute of International Economics, imposition of unilateral sanctions has spectacularly failed at 34\% for 16 cases studied from 1914 to 1990. Current figures from World Finance postulate the success rate to be as low as 20-30\%. Cashen (2017) observes failure of economic sanctions imposition dating back to $432 \mathrm{BC}$ when the Athenian Empire levied unsuccessful economic sanctions against neighbouring Megara State which consequently failed [5].

The question of effectiveness of sanctions has drawn a lot of asymmetrical arguments in terms of how and under what conditions sanctions work. U-Jin Ang et al (2007) submits that in sanctions repertoire and narratives, there had not been systematic analysis on the role and salience of sanctions, their effectiveness and their effect. In a Select Committee on Economic Affairs $2^{\text {nd }}$ report of Session 2006-07 entitled "The Impact of Economic Sanctions. Volume 1 Report" The British House of Lords, under Chapter 7, Section 109 highlights that:

...economic sanctions used in isolation from other policy instruments are extremely unlikely to force a target to make policy changes, especially where relations between the states involved are hostile more generally...

...even when economic sanctions are combined effectively, with other foreign policy instruments, on most occasions they play subordinate role to those other instruments. Economic sanctions can be counter-productive in a variety of ways, including when more vigorous cohesion in the form of force is needed but is forestalled by those making inflated claims for the value of sanctions as an alternative. Sanctions can also be counter-productive when what is required is much greater emphasis on economic, diplomatic and security incentives...furthermore, when the use of economic sanctions for this purpose is proposed, serious consideration should be given to the possibility that their overall effect will be counter-productive, even in symbolic terms...

What is important in the above clause is "where relations between the states involved are hostile". That qualification calls for the closer analysis of the nature of post-independence and especially post land reform relations between Britain and Zimbabwe. In 1997, New Labour government came to power. Difficulties in foreign policy relations, colonial baggage and neo coloniality are documented by Miyagawa, M. (1992), Herbst (1991), Lewis (2008), Raftopolous (2009), Ndlovu-Gatsheni (2009), Sithole (2015), Alexander et al (2017)

\section{Findings: Sanctions and Their Effectiveness}

Studies by McGillivray \& Stam (2004), Bolks, \& Al-Sowayel, (2000) and focus on effectiveness of international economic sanctions as a tool for coercive diplomacy. Coercive success or failure of international sanctions is limited because it is practically impossible to tell how long they should last to achieve substantive goals. In the case of the US sanctions against Cuba, they remained in place for decades under which the Cuban health delivery system developed to be one of the best models in the world. One reason why economic sanctions are withdrawn is when they succeed in bringing about change in policy or leadership in the target state. After Robert Mugabe proceeded to win for two terms of elections [after the imposition of sanctions through Zimbabwe Democracy Act and Recovery Act of 2001], Western diplomacy had no idea of how else they should handle him. The opposition Movement for Democratic Change (MDC) in Zimbabwe was in disarray as ZANU PF still commanded a lot of grassroots support especially in rural areas. We note that the rural populace of Zimbabwe bore most of the brutal brunt of the Chimurenga wars of liberation because of their intense involvement in and support of the liberation war.

The fact that in November 2017, Mugabe was succeeded by [his] Vice-President, Emmerson Mnangagwa - who rose to 
Presidency from the same ZANU PF party - does not signify in any way, a regime change agenda, but perpetuation of same philosophical ethos represented by the party. In his inaugural address President Mnangagwa has indicated at government policy level that Zimbabwe land reform will not be reversed but reformed to fit contextual changes of capacity building and optimal food security through high productivity. In his Acceptance Speech delivered by the new President at his inauguration on 24 November 2017, he specifically said that:

Dispossession of our ancestral land was the fundamental reason for waging the liberation struggle. It would be a betrayal of the brave men and women who sacrificed their lives in our liberation struggle if we were to reverse the gains we have made in reclaiming our land...

...as we go into the future, complex issues of land tenure will have to be addressed both urgently and, to ensure finality and closure to the ownership and management of this key resource which is central to our national stability and to sustained economic recovery. We dare not prevaricate on this key issue... [6]

Although this was not what the British expected, President Mnangagwa referred to total decoloniality of Southern Africa, hinting in the process, that South Africa was next in line. The ordinary citizens of Zimbabwe are imbued with self-consciousness and belief - a mutation of ZANU PF core beliefs. Said "Cde Muzvinavhu” (Meaning "rightful owner of land")

... An important assertion on our land reform. We entrenched our land reform in our new constitution. Our President is spot on. The reprisal from the West did not dampen our revolutionary spirit, when sanctions were applied to punish us. Today we walk with our shoulders and heads up, while we take measures to improve its utilization. We are celebrating our Independence with dignity. It is heartening that our brothers and sisters in South Africa have now come to this important verge of land reform... They will learn from our takes and mistakes, but the bottom line is the necessary land reform to give credence and dignity to their freedom from satanic apartheid. A neo apartheid economy in $S$ Africa without land reform is anathema in Africa....

[Taken from 'Our land is for Zimbabweans: President': $38^{\text {th }}$ Independence Celebration found at https://www.herald.co.zw/our-land-is-for-zimbabweans-president/Accessed April 18,]

\section{Descriptive formulation of the impact of economic sanctions on Zimbabwe}

a. Economic Decline after Economic Sanctions in 2001:

Table 1. Selected Macroeconomic Indicators

\begin{tabular}{|c|c|c|c|c|c|c|c|}
\hline Indicator & 2000 & 2001 & 2002 & 2003 & 2004 & 2005 & 2006 \\
\hline GDP (current US\$ million) & $8,135.8$ & $12,882.6$ & $17,875.6$ & $7,913.1$ & $4,712.1$ & $3,372.5$ & $7,033.7$ \\
\hline GNP & $7,150.0$ & $12,800.0$ & $30,800.0$ & $7,850.0$ & $4,640.0$ & $3,180.0$ & n.a. \\
\hline Population & $12,595.0$ & $12,698.0$ & $12,786.0$ & $12,863.0$ & $12,936.0$ & $13,010.0$ & $13,085.0$ \\
\hline $\begin{array}{l}\text { Current account balance (as \% of } \\
G D P \text { ) }\end{array}$ & -0.4 & -1.0 & -2.6 & -4.6 & -5.6 & -7.5 & -4.0 \\
\hline $\begin{array}{l}\text { Fiscal deficit, including grants (\% of } \\
G D P)\end{array}$ & -18.6 & -7.0 & -2.7 & -0.2 & -7.6 & -6.1 & -3.1 \\
\hline GNS per GDP $(\%)$ & 11.1 & 7.0 & 4.9 & -1.4 & -3.2 & -6.7 & 4.0 \\
\hline $\begin{array}{l}\text { Gross of official reserves (months of } \\
\text { imports) }\end{array}$ & 1.5 & 0.6 & 0.7 & n.a. & n.a. & n.a. & n.a. \\
\hline GDP growth rates & -7.3 & -2.7 & -4.4 & -10.4 & -3.8 & -6.5 & -5.1 \\
\hline CPI inflation & 55.6 & 73.4 & 133.2 & 365.0 & 350.0 & 237.8 & $1,216.0$ \\
\hline
\end{tabular}

Sources: African Development Bank database; IMF (for balance-of-payments current account balance) - page 12

The figures above appear inconsistent partly because of the numerous currency conversions that took place between 2005 to date. The Reserve Bank at that time removed zeros from the currency many times in an effort to manage thereby distorting micro-economic indicators. This partly explains skewed measures of GDP. There are other factors like how the effects of the disastrous Economic Structural Adjustment programme (ESAP) implemented in the mid 1990's hit industrial growth especially in the manufacturing sectors and heavy industries, decline of the agricultural sector due to farm occupations, decline in real wages of consumers, poor management of the economy including budget deficit due to unsustainable borrowing and shortages of foreign currency.

\section{Repealing Sanctions}

As a step towards repealing ZDERA, conclusions from Zimbabwe Council of the European Union Brussels, 22 January 2018 (OR. en) 5169/18 COAFR 8 CFSP/PESC 19 adopted the following key resolutions at its $3591^{\text {st }}$ meeting held on 22 January 2018 [7]. Note that the 'position' means adopting a wait and see attitude designed to give Western European and the US space in which to regroup. The West continues to work with opposition cabals in the cast of 'political figures' and 'civic groups' in Zimbabwe - in finding devious ways of dismantling powerful ruling party ZANU PF. 


\section{Zimbabwe Democracy and Economic Recovery Amendment Act 2018}

On 22 March 2018 the US Congress amended the Zimbabwe Democracy and Economic Recovery Act 2001 through a Bill cited as "S. 2595 - 115th Congress: A bill to amend the Zimbabwe Democracy and Economic Recovery Act of 2001." www.GovTrack.us. 2018 [8].

At the time of writing this report (April 2018), S. 2595 is a bill in the United States Congress waiting for President Trump's approval - A bill must be passed by both the House and Senate in identical form and then be signed by the President to become law.

The original Act of 2001 which is four pages in length has burgeoned to nine pages, incorporating changes demanded by opposition politics in Zimbabwe. The current bill is an incorporation of the Movement for Democratic Change (MDC) electoral reforms demands. These demands are precariously designed to squeeze out ZANU PF and its liberation struggle ideology from political space in Zimbabwe.

Section 2 headed 'Reconstruction and Rebuilding of Zimbabwe' is a presumption that previous and enduring land reforms of ZANU PF are detrimental to social and democratic turf in Zimbabwe. The bill works on the premises that Zimbabwe needs to be 'reconstructed' and must be 'configured' to represent and protect Western interests including land, mines and mineral ores. ZANU PF perceives this move as attempts to propel western created opposition MDC to power for reasons of gatekeeping imperial Western interests.

In 5 (4) (2) the bill seeks to withhold funding for the African Development Bank for arrears clearance - revealing another punitive measure and sabotage directed at and designed to bring the Mnangagwa-led government to its knees. Pre-election conditions in 6 (2) (a-f) are destined to foster western democracy that fosters neo-colonial imperatives - in terms of controls and governance. The enormity of demands is also implied to intimidate the ZANU PF revolutionary party into capitulation exceptionally at this pre-election time when it is in a dog fight for its legitimacy. According to ZANU PF, such overt threats not only go against the thread and reason of Chimurenga liberation philosophy but distorts the history and mindset of the younger electorate.

We also witness through the provisions of the same bill perverted efforts to dictate what to and not include into the Zimbabwean constitution. For example, under 6 (4) the US and its allies calls for statutory 'amendments' and updates of statutes again rendering their roles to those of dictators:

"Laws enacted prior to passage of Zimbabwean constitution in March 2013 that are inconsistent with the new constitution are amended or repealed so that they are consistent with the constitution"

Who are they to call for insertions or invalidations of certain provisions of the law into the Zimbabwean constitution? Is it not striking coincidence that one such constitutional provision relates to the disbanded and moribund SADC Tribunal on Zimbabwean Land ruling? As far as President Mnangagwa ruling ZANU PF party is concerned, implications are far reaching because recognising judgements from the said tribunal is tantamount to reversal of the land reform programme itself. (See Section 10, of the Bill, headed "SADC Tribunal Rulings" involving 18 disputes with original looters, so called [and dignified and exalted as] 'Zimbabwean Commercial Farmers'!

Why is the US obdurate and adamant in its support of opposition MDC? (i) It is their project created to frustrate land reform and empowerment; (ii). MDC supports market reforms that favour capitalism whereas ZANU PF advocates for market reforms designed to empower its people. Check on Zim-Asset versus MDC economic blueprint - The MDC's economic proposals are encapsulated in the "JUICE plan" - an acronym for "jobs, upliftment, investment capital and the environment; (iii). By redistributing land without compensation, a tit for tat that corrects preceding colonial and historical antecedents and banalities, ZANU PF deals a hard blow to imperialism, (iv). If MDC, calls for restoration of property rights - it is a call to preserve capitalism. This is so because the heart of capitalism world over is property rights and profit accretion through creation of equity.

We all know that land is equity. ZDERA is therefore a formulation of a bible of capitalism in Zimbabwe which - of course, is being managed by and implemented for the benefit of MDC at the behest of their Western cohorts. We also all know that capitalist market reforms foster creation of stagnation and underdevelopment by perpetuating exploitation. Che Guevara was succinct:

'These characteristics are not fortuitous; they correspond strictly to the nature of the capitalist system in full expansion, which transfers to the dependent countries the most abusive and barefaced forms of exploitation. It must be clearly understood that the only way to solve the questions now besetting mankind is to eliminate completely the exploitation of dependent countries by developed capitalist countries, with all the consequences that this implies.' ${ }^{1}$ 
In Chapter (vi) titled The African Constitution Birth of Democracy, Williams (1987) in his book The Destruction of Black Civilization, contends that what matters the most is the concept and application of African democracy as part of African judiciary system. Such a system is determined by evolution of their history derived from customary rules of their life. It is also shaped by humanly-constructed depravation and abomination in terms of dispossessions and disempowerment, colonial practices of theft by conversion and eighteen century imperialisms. It can never be 'primitive democracy' but part of systems and structures of their governance. Zimbabwe's constitution of 1979 is born out of coloniality and imperialism while the 2013 constitution is the ultimate process of addressing the evils of neo-colonialism - and that argument has always been crystal clear. "Tonho"!... sa President Mugabe na Madhuku [9]

\section{Observations Recommendations and Conclusions}

i. How were sanctions imposed on Zimbabwe in the first place? Following Chimurenga 3 from 2000, Zimbabwe case was taken to the United Nations Security Council originally to seek military intervention. Because of the composition of the UN Security Council, USSR and China refused to veto that UN Security Council Resolution on Zimbabwe. Britain quickly cobbled sanctions option which was taken up for alleged human rights abuses [mostly against white farmers]. The UN Security Council adopted the 'less devastating' option (as opposed to military intervention). This was approved by the European Union. This means is that Zimbabwe must approach its devil masters through the EU for lifting of odious sanctions. Whether the Mnangagwa-led government will accept US-EU terms and conditions remains a matter for intense debate.

ii. Brexit is an acronym coined by the David Cameroon-led Conservative government based on the results of the referendum on June 23, 2016 to leave the European Union. The term means "British exit" is based strictly on legislative and economic guidelines of leaving the EU, a regional Trade Agreement (RTA) body of 29 countries. The regional block eliminates trade barriers and bureaucracy for ease of doing business through harmonization of laws, movement of goods and people across continental Europe for its member states. The European Commission based in Brussels presides over the harmonization of the single monetary currency, the euro for this block although Britain chose to be out of the euro zone when it was introduced in 1999. Leaving the EU has adverse implications for Britain in terms of World Trade Organisation (WTO) obligations as stated in the General Agreement of Trade in Services (GATS), ushers limited investment opportunities and a strain on the UK export market. Restricted access to the EU is likely to force the UK to look for alternatives by strengthening imperialistic organisations like the Commonwealth of Nations.

iii. Because of the rich mineral ore resources that Britain and preys on and pilfers, Zimbabwe remains a strategic but unequal partner in international capital. In the book entitled "War on Want: The New Colonialism Britain's scramble for Africa's energy and mineral resources", Curtis (2016) notes that:

...the continent of Africa is today facing a new colonial invasion, no less devastating in scale and impact than that which it suffered during the nineteenth century. As before, the new colonialism is driven by a determination to plunder the natural resources of Africa, especially its strategic energy and mineral resources. At the forefront of this 'scramble for Africa' are British companies actively aided and abetted by the UK government...

... Under the guise of the UK helping Africa in its economic development, (a mere continuation of the colonial paternal narrative), $\$ 134$ billion has flowed into the continent each year in form of loans, foreign investment and aid. However, the British government has aided and abetted the extraction of $\$ 192$ billion from Africa mainly in profits by foreign companies, tax dodging and the cost of adapting to climate change...

iv. Specifically, on Zimbabwe, the following facts by Curtis (2016) are precisely valid:

... Anglo American corporation which operates in South Africa and Zimbabwe controls 200 million ounces of platinum, and produces $40 \%$ of the world's newly mined platinum and operates Unki platinum mines in Zimbabwe, it owns $50 \%$ interest in the Mimosa Mine on a 50/50 share agreement with Anglo platinum, Amplats, Caledonia Mining Corporation incorporated in Canada for Gold Zimbabwe owns $49 \%$ in the Blanket Gold Mine in the South West, which produces an average of 192000 ounces of gold. The remaining 51\% is owned by Zimbabweans, In Mwana Africa PLC (Asa Resource Group PLC) incorporated in the UK, Zimbabwe owns 85\% of Fred Rebecca Gold Mine which contains vast resources of the Hunter Road Nickel deposits resources and the company is exploring and developing Makaha Gold deposits. It has $75.4 \%$ interests in Bindura Nickel Corporation which owns and operates Shangani and Trojan nickel mines which produced $\$ 102$ million worth or mineral ores in 2014 despite economic sanctions constraints. Premier African Minerals BVI is incorporated in the British Virgin Islands. Zimbabwe has two projects exploring rare earth, wolframite. Sable Mining Africa incorporated in the BVI is developing the Lubu Coal Project in the North West of Zimbabwe covering 19236 hectares which contains 786 tonnes and has an interest in Lubibi Coal projects in the west covering 16545 hectares with resource base of 1 billion tonnes. Vast Resources incorporated in the UK mines gold where Zimbabwe has 50\% interest in Breckridge Investments Ltd (a joint venture between Vast Resources and Grayfox 
Investments) - which holds 100\% interest in the Pick Stone Peerless Gold Mine and mining claims surrounding former Giant Mine. The Zimbabwean mine contains 3.56 million ounces of Gold... [Data compiled from page 35-69]

The above list of foreign owned and mostly British owned companies is not exhaustive.

v. Sanctions will be removed for two reasons - first to facilitate ease of exploitation and extraction of resources which benefit Britain the most; second - to counter threat of competition from Eastern Bloc Countries, including China and Russia who are traditional friends of Zimbabwe in its struggle against British colonial and oppressive rule. Britain wants to consolidate its grip on Zimbabwean resources under smokescreens investment opportunities.

vi. At another level, there is an ideological warfare between the west and former socialist block countries. Britain perceive the later negatively as they claim that China and Russia be a new front for imperialism and economic windfall - without shedding an iota of blood or firing a single bullet in Zimbabwe.

vii. In the historical analysis of Britain foreign policy, we bring to the fore that Britain is not new to Brexit. Brexit (23 June 2016) is a modernised form of Splendid Isolation which dominated British war time history in the $19^{\text {th }}$ Century. Following the Crimean war (1853 -1856) under Prime Minister Lord Palmerston (1855-1858), Britain voluntarily entered isolation from 1902 to 1939, for pursuing economic interests and expansion of its empire. This was regulated by colonial boundaries, spheres of influence and power, trade routes and markets, tariffs and treaties that propped her government in maintaining the balance of power.

viii. Although the forms of economic relationships at that time vary, splendid isolation was an attempt to protect the British Empire by keeping out of European affairs. If we fast forward to March 29, 2017 when Britain triggered Article 50 of the Lisbon Treaty (2007) (a2009) to exit the European Union: the pattern is the same as Britain seeks to engage its own trading alliances by strengthening her position with its weakened former colonies. It is a fact that the less developed and over-exploited former colonies notably in Africa have emerged worse off in terms of capital accumulation and globalisation at the turn of the millennium. Against that setting, Zimbabwe remains a target for re-colonialization and neo-colonization.

\section{Conclusion}

This paper has contributed to the current thesis and analysis of Zimbabwean sanctions in terms of their roots, destructive engagement, underdevelopment and destruction of the country. This study does not delve into derivative or quantitative statistics on how economic sanctions have affected Zimbabweans because it is outside that remit. In terms of future directions and current developments, it is possible for the United Kingdom to move faster and normalize relations with its former colony - as it is within its interests under Brexit. Establishing as many bi-lateral relations as possible will create a buffer zone aimed at driving competing forces from the East. Presently, Zimbabwe is crowded space, a battleground where western countries are competing for breathing space. Because of the extent to which the Zimbabwe economy has been [deliberately] battered by years of unrelenting economic sanctions, it is possible to perceive Zimbabwe as a desperate regime begging hat in hand for investments. But reality is that western countries, especially the UK is under extensive pressure to claw back lost ground over the past two decades. Zimbabwe must use that as a bargaining trump card. The new government must come up with a tangible economic agenda designed to manage not only the post-Mugabe era, but imperialism and neo-colonialism. Rodney's thesis of How Europe Underdeveloped Africa is applicable to the context of how British-induced economic sanctions have underdeveloped Zimbabwe in almost all sectors of the economy.

\section{Notes}

[1] S Moyo \& P Yeros, 'The radicalised state: Zimbabwe's interrupted revolution', Review of African Political Economy, 111, p. 106 (2007).

[2] J Hatchard, 'The constitution of Zimbabwe: towards a model for Africa'. Available at https://doi.org/10.1017/S0021 85530000008378/Accessed 13 Feb 2017.

[3] C Mararike, 'West making fortunes from plundered African resources'. Available at https://www.mail-archive.com/ugandanet@kymnet/msg01362.html/ Accessed 7 Feb 2017.

[4] Chibharo is a Shona noun derived from a radical 'kubata chibharo' which means committing statutory rape. The symbolism of the use of Chibharo especially in Rhodesian mines is that men were rounded up against their will by the colonial regime and forced to work as wage labours. Exploitation of African cheap labour was rife and unchecked by the repressive regime of the day.

[5] Cashen, Emily 2017 http://www.worldfinance.com/special-reports/the-impact-of-economic-sanctions. Accessed Jan $2,18$. 
[6] President Mnangagwa inauguration speech in full, The Chronicle. http://www.chronicle.co.zw/president-mnangagwas-inauguration-speech-in-full/; Accessed Jan 2, 18

[7] Zimbabwe: Council adopts conclusions in light of ongoing political Transition at http://www.consilium.europa.eu/en/press/press-releases/2018/01/22/zimbabwe-council-adopts-conclusions-in-light-of-o ngoing-political-transition/ Accessed 29 Jan 18.

[8] March 25, 2018 https://www.govtrack.us/congress/bills/115/s2595

[9] See The Survival Strategy: Mugabe's 83 Birthday Interview on You Tube, at https://www.youtube.com/watch?v=5Mq0cVE7AmU/Accessed Mar 18

\section{References}

Alexander, J. (2006). The Unsettled Land: State Making and The Politics of Land in Zimbabwe:1983-2003, Oxford, James Curry, 2006.

Bolks, S. M., \& Al-Sowayel, D. (2000). 'How do economic sanctions Last? Examining the sanctions process through duration' Sage Journals. Political Research Quarterly, 53(2), 241-265. https://doi.org/10.1177/106591290005300202

Clyde-Hufbauer, Jeffrey, G., Schott, J., \& Ann Elliott, K. (1985) Economic Sanctions Reconsidered: History and Current Policy, Institute for International Economics, United States of America. Found at: https://books.google.co.uk/books?hl=en\&lr=\&id=etyVmnPOrG8C\&oi=fnd\&pg=PR11\&dq=Schott+(1985)+sancti ons\&ots=Tf7DhiV8-R\&sig=WaGbwJ_Nsitl-171QaXWaGyaLrc\#v=onepage\&q=Schott\%20(1985)\%20sanctions\&f $=$ false/Accessed/April.29.18

Curtis. (2016). "War on Want: The New Colonialism - Britain's scramble for Africa's energy and mineral resources", Found at

https://waronwant.org/resources/new-colonialism-britains-scramble-africas-energy-and-mineral-resources/Accesse d April29, 18

Fanon, F. (2008). Black Skin White Masks, Pluto Press, London, United Kingdom.

Galtung, J. (1967). 'On the Effects of International Economic Sanctions: With Examples from the Case of Rhodesia'. World Politics, 19(3), 378-416. https://doi.org/10.2307/2009785

Helmes, J. (1999). 'What sanctions epidemic?' Foreign Affairs, 78(1), 2-8. https://doi.org/10.2307/20020234

Jing, C., Kaempfer, W. H., \& Lowenberg, A. D. (2003). 'Instrument choice and effectiveness of international sanctions: a simultaneous approach'. Journal of Peace and Research, 40(5), 519-535. https://doi.org/10.1177/00223433030405002

Lewis, R. (1980). 'From Zimbabwe-Rhodesia to Zimbabwe'. Round Table, 70, 6-9. https://doi.org/10.1080/00358538008453415

Mararike, M. (2018). 'Theoretical Locations of Mugabeism, Land "Terrorism," and Third Chimurenga Neo-Coloniality Discourse in Zimbabwe: A Rejoinder of a Revolutionary'. 49(3), 191-211, Article first published online: March 20, 2018; Issue published: April 1, 2018.

McGillivray \& Stam, A. C. (2004). 'Political institutions, coercive diplomacy, and duration of economic sanctions'. Journal of Conflict Resolution, Sage Journals, 48(2), 154-172. https://doi.org/10.1177/0022002703262858

Miyagawa, M. (1992). Do Sanctions work? Macmillan, London, Great Britain.

Muller, J., \& Muller, K. (1999). 'Sanctions of Mass Destruction'. Foreign Affairs, 78(3), 43-53. https://doi.org/10.2307/20049279

Ndhlovu-Gatsheni, S. J. (2009). 'Making sense of Mugabeism in Local and Global Politics: 'So Blair, keep your England and let me keep my Zimbabwe'. Third World Quarterly, 30(6), 1139-1158. https://doi.org/10.1080/01436590903037424

Portela, C. (2010). European Union Sanctions and Foreign Policy: When do the work? Routledge-Taylor \& Francis Group, Oxon, United Kingdom.

Raftopolous, B (2009) 'The Crisis in Zimbabwe 1998-2008' ResearchGate at http://www.researchgate.com/282076567_The _Crisis_in_Zimbabwe_1998-2008_Brian_Raftopoulos/ Accessed Jan 29, 18.

Rodney, W. (1972). How Europe Underdeveloped Africa, Bogle-L'Ouvertune Publications, London, UK.

Sandler, T., \& Hartley, K. (2007). Handbook of Defence Economics: Defence in a Globalised.

Sithole, T. (2015). 'A Fanonian reading of Mugabe as a colonial subject', Mugabeism? 217-236.

Tendi, B. M. (2014). 'The Origins and Functions of Demonization Discourses in Britain-Zimbabwe Relations (2001-)' 
Journal of Southern African Studies, 40(6), 1251-1269. https://doi.org/10.1080/03057070.2014.933646

Van Berggeijk, P. A. (1989). 'Success and failure of economic sanctions'. Kyklos, 42(3), 385-404. https://doi.org/10.1111/j.1467-6435.1989.tb00200.x

Van Onseleen, C. (1976). Chibaro: African Mine Labour in Southern Rhodesia 1900-1933. Pluto Press, London.

Von Braunmuhl, C., \& Kulessa, M. (1995). 'The impct of UN sanctions on humanitarian assistance activities, Berlin Gesellschaft fur Communication management Interkultur Training.

Weiss, T. G. (1999). 'Sanctions as a foreign policy tool: weighing humanitarian impulses'. Journal of Peace Research, 36(5), 499-509. https://doi.org/10.1177/0022343399036005001

Williams, C. (1987). Destruction of Black Civilization: Great Issues of a Race from 4500BC to 2000AD, Third World Chicago Press, USA.

\section{Copyrights}

Copyright for this article is retained by the author(s), with first publication rights granted to the journal.

This is an open-access article distributed under the terms and conditions of the Creative Commons Attribution license which permits unrestricted use, distribution, and reproduction in any medium, provided the original work is properly cited. 